\title{
O TRIBUNAL DO JÚRI E A INCONSTITUCIONALIDADE DA EXECUÇÃO PROVISÓRIA DAS CONDENAÇÕES: UMA ANÁLISE À LUZ DOS PRECEDENTESE DA MÁXIMA DA PROPORCIONALIDADE
}

\author{
THE JURY COURT AND THE UNCONSTITUTIONALITY \\ OF THE PROVISIONAL EXECUTION OF THE CUSTODIAL \\ SENTENCES: AN ANALYSIS IN THE LIGHT OF CASE LAW \\ AND THE MAXIMUM OF PROPORTIONALITY
}

\section{Natacha Back ${ }^{1}$}

Resumo: A temática do presente artigo diz respeito à possibilidade de execução provisória das penas privativas de liberdade impostas pelo Tribunal do Júri no ordenamento jurídico brasileiro. Busca-se, partindo da hipótese de que a medida é incompatível com os princípios consagrados na Constituição da República Federativa do Brasil de 1988, expor os posicionamentos favoráveis e contrários, bem como demonstrar sua possível inconstitucionalidade. $\mathrm{O}$ estudo foi desenvolvido utilizando-se o método de abordagem dedutivo, por meio de uma metodologia qualitativa, descritiva, prescritiva e baseada em pesquisas bibliográficas, incluindo livros, artigos, legislações e consultas a sítios de órgãos públicos, além de precedentes do Supremo Tribunal Federal e Superior Tribunal de Justiça, a fim de possibilitar maior compreensão no que tange à Lei n ${ }^{0}$ 13.964/19 e aos princípios da soberania dos vereditos, do estado de inocência e do duplo grau de jurisdição. A partir da análise desses institutos e com aporte na regra da proporcionalidade, segundo a teoria dos direitos fundamentais de Robert Alexy, o resultado obtido, mediante sopesamento moral exigido pela proporcionalidade em sentido estrito, foi no sentido de que o cumprimento imediato das condenações do Júri não é razoável e viola princípios basilares do Estado

1. Graduanda em Direito pela Universidade Federal de Santa Catarina (UFSC).E-mail: natachaback@hotmail.com 
Democrático de Direito, devendo prevalecer o direito à liberdade e ao duplo grau de jurisdição do acusado.

Palavras-chave: Execução provisória da pena. Soberania dos vereditos do Tribunal do Júri. Estado de inocência. Duplo grau de jurisdição. Proporcionalidade.

Abstract: The article is about the possibility of provisional execution of custodial sentences imposed by the Jury Court in the Brazilian legal system. It is sought, based on the hypothesis that the measure is incompatible with the principles enshrined in the Constitution of the Federative Republic of Brazil of 1988, to expose the favorable and contrary positions, as well as to demonstrate their possible unconstitutionality. The study was developed using the deductive approach method, through a qualitative, descriptive, prescriptive methodology and based on bibliographic research, including books, articles, legislation and consultations in websites of public agencies, in addition to the placements of the Supreme Federal Court and the Superior Court of Justice, in order to enable a greater understanding of the Law $n^{0} 13.964 / 19$ and the principles of the sovereignty of verdicts, the state of innocence and the double degree of jurisdiction. From the analysis of these institutes and based on the proportionality rule, according to Robert Alexy's theory of fundamental rights, the result obtained, through moral weighing required by proportionality in the strict sense, was in the sense that the immediate fulfillment of the Jury's condemnations is not reasonable and violates basic principles of the democratic rule of law, and the right to freedom and the double degree of jurisdiction of the accused should prevail.

Keywords: Provisional execution of the sentence. Sovereignty of the Jury`s verdicts. Stateofinnocence. Doubledegreeofjurisdiction. Proportionality.

\section{INTRODUÇÃO}

Em um primeiro momento, o debate que envolve a possibilidadede o cumprimento imediato da pena não se refere tão somente às sentenças proferidas pelo Conselho de Sentença, mas a qualquer condenação criminal não substituída por restritivas de direitos. Até o ano de 2009, o 
Supremo Tribunal Federal (STF) entendia que a presunção de inocência não impedia a execução de pena confirmada em segunda instância; contudo, no julgamento do Habeas Corpus (HC) n ${ }^{\circ} 84.078 / \mathrm{MG}$, a Corte decidiu que o encarceramento estaria condicionado ao trânsito em julgado da condenação, ressalvada a possibilidade de prisão preventiva.

Modificando o entendimento consolidado, admitiu-se, no $\mathrm{HC} \mathrm{n}^{\circ}$ 126.292 julgado em 2016, o cumprimento de pena antes do seu trânsito em julgado, desde que esgotados os recursos perante as instâncias ordinárias. O Plenário, por maioria de votos, considerou que essa medida não ofenderia o princípio constitucional da presunção de inocência, uma vez que, segundo o relator Min. Teori Zavascki, a manutenção da sentença penal, pela segunda instância, encerra a discussão sobre os fatos e as provas do caso, motivo pelo qual autorizaria o início de sua execução (BRASIL, 2016, p. 9).

A fim de evitar os efeitos da decisão, em maio do mesmo ano, o Partido Ecológico Nacional (PEN) (atual Patriota) e o Conselho Federal da Ordem dos Advogados do Brasil (OAB) ajuizaram as Ações Declaratórias de Constitucionalidade $n^{\circ} \mathrm{s} 43$ e 44, respectivamente, ao passo que o Partido Comunista do Brasil (PCdoB) ajuizou a ADC n $54 \mathrm{em}$ abril de 2018. As três tendo por objeto, novamente, o questionamento acerca da possibilidade de se iniciar o cumprimento da pena antes de esgotadas todas as vias recursais. Deliberadas em conjunto, foi declarada a inconstitucionalidade da execução provisória da pena privativa de liberdade em face do princípio da presunção de inocência, restabelecendo o posicionamento anterior, bem como a compatibilidade do art. 283, caput, do Código de Processo Penal, o qual dispõe que "ninguém poderá ser preso senão em flagrante delito ou por ordem escrita e fundamentada da autoridade judiciária competente, em decorrência de prisão cautelar ou em virtude de condenação criminal transitada em julgado" (BRASIL, 1941), com a Constituição Federal. Contudo, o presidente da Corte, Min. Dias Toffoli, afirmou, ao final do julgamento, que o entendimento firmado não deveria abranger as condenações pelo Conselho de Sentença, nos crimes dolosos contra a vida, por se tratarem de decisões soberanas (BRASIL, 2019b, p. 477). 
Com a aprovação da Lei no 13.964/2019, a questão controvertida renasce alicerçada na incerteza quanto à constitucionalidade da previsão que possibilita executar de forma imediata as sentenças condenatórias proferidas pelo Tribunal do Júri. Reconhecida a repercussão geral da matéria por unanimidade, o tema está atualmente em pauta no Recurso Extraordinário $\mathrm{n}^{\mathrm{o}}$ 1.235.340 e, embora com seu julgamento suspenso, já conta com o voto do relator Min. Luís Roberto Barroso no sentido da possibilidade da medida, independente da pena.

$\mathrm{O}$ presente trabalho, recorrendo à pesquisa bibliográfica, utilizou o método de construção dedutivo e o vasto leque de discussões no que diz respeito à (in)constitucionalidade da execução da pena antes de percorrida toda a cadeia recursal, no âmbito do processo penal brasileiro, como marco teórico referencial. Os argumentos favoráveis e contrários à medida encontrados serão apresentados, para fins meramente didáticos, em duas correntes, idealizadas pelo estudo exclusivamente para esse fim, analisando o debate a partir da regra da proporcionalidade, elucidada pela teoria de Robert Alexy, especialmente no que se refere à colisão entre princípios e à maneira adequada de se aplicar o sopesamento nesses casos.

A priori, imprescindível apresentar as modificações levantadas pela Lei $\mathrm{n}^{\mathrm{o}}$ 13.964/19 no âmbito do Tribunal do Júri, principalmente quanto à nova redação da alínea "e" do art. 492, inciso I, do Código de Processo Penal, e sua relação com o princípio da soberania dos vereditos, previsto no art. 50, inciso XXXVIII, alínea “c”, da Constituição da República Federativa do Brasil de 1988. O segundo capítulo, por sua vez, busca elucidar os princípios do estado de inocência, disposto no art. $5^{\circ}$, inciso LVII, da Carta Magna, e do duplo grau de jurisdição, instituído pelo art. $8^{\circ}$, item 2, alínea "h", do Pacto de São José da Costa Rica de 1969, assim como a importância deles na persecução penal. Pretende-se, por fim, demonstrar a inconstitucionalidade da execução provisóriapor meio da ponderação entre os principais direitos fundamentais em conflito - liberdade do acusado e proteção à ordem pública -, dos entendimentos dos tribunais e doutrinários, como também por intermédio da própria legislação processual penal. 


\section{LEI N. 13.964/2019 E O PRINCÍPIO DA SOBERANIA DOS VEREDITOS}

A primeira corrente instituída pela pesquisa defende a execução provisória das decisões do Tribunal do Júri com fundamentona soberania dos vereditos. Assim, serão inicialmente expostas as modificações sofridas pela legislação penal e processual penal, visando à eficiência do aparelho estatal durante a persecução criminal, em razão da aprovação da Lei n ${ }^{\circ} 13.964$, de 24 de dezembro de 2019, em vigor desde 23 de janeiro de 2020, proveniente do projeto denominado de Pacote Anticrime.

No que tange ao Tribunal do Júri, além de incluir os $\S \S 3^{\circ}$ ao $6^{\circ}$, a lei deu uma nova redação à alínea "e" do art. 492, inciso I, do Código de Processo Penal, acrescentando a possibilidade de execução provisória da pena privativa de liberdade igual ou superior a 15 anos. Passou a determinar:

Art. 492. Em seguida, o presidente proferirá sentença que:

I - no caso de condenação:

[...]

e) mandará o acusado recolher-se ou recomendá-lo-á à prisão em que se encontra, se presentes os requisitos da prisão preventiva, ou, no caso de condenação a uma pena igual ou superior a 15 (quinze) anos de reclusão, determinará a execução provisória das penas, com expedição do mandado de prisão, se for o caso, sem prejuízo do conhecimento de recursos que vierem a ser interpostos.

[...]

$\S 3^{\circ} \mathrm{O}$ presidente poderá, excepcionalmente, deixar de autorizar a execução provisória das penas de que trata a alínea e do inciso I do caput deste artigo, se houver questão substancial cuja resolução pelo tribunal ao qual competir o julgamento possa plausivelmente levar à revisão da condenação.

$\S 4^{\circ} \mathrm{A}$ apelação interposta contra decisão condenatória do Tribunal do Júri a uma pena igual ou superior a 15 (quinze) anos de reclusão não terá efeito suspensivo.

$\S 5^{\circ}$ Excepcionalmente, poderá o tribunal atribuir efeito suspensivo à apelação de que trata $\mathrm{o} \S 4^{\circ}$ deste artigo, quando verificado cumulativamente que o recurso:

I - não tem propósito meramente protelatório; e 
II - levanta questão substancial e que pode resultar em absolvição, anulação da sentença, novo julgamento ou redução da pena para patamar inferior a 15 (quinze) anos de reclusão.

$\S 6^{\circ} \mathrm{O}$ pedido de concessão de efeito suspensivo poderá ser feito incidentemente na apelação ou por meio de petição em separado dirigida diretamente ao relator, instruída com cópias da sentença condenatória, das razões da apelação e de prova da tempestividade, das contrarrazões e das demais peças necessárias à compreensão da controvérsia. (BRASIL, 1941).

A partir da norma transcrita, cristalino o condicionamento ao montante da pena imposta na sentença para o encarceramento, isto é, somente na hipótese de condenação a uma pena igual ou superior a 15 anos de reclusão será determinada a execução provisória da sanção, com expedição de mandado de prisão. Nesse caso, conforme o $\S 4^{\circ}$, não será concedido o efeito suspensivo em eventual apelação interposta.

Não obstante, a nova lei prevê ressalvas. O $\S 3^{\circ}$ estabelece que o Juiz-Presidente pode, excepcionalmente, deixar de aplicar a execução temporária da pena quando o recurso interposto tratar de questão substancial, cuja decisão pelo tribunal competente possa levar à reconsideração da condenação. Já o $\S 5^{\circ}$ dispõe que o efeito suspensivo poderá ser deferido, também em situações excepcionais, quando preenchidos os requisitos cumulativos previstos nos incisos I e II, sendo que a suspensão da eficácia da sentença condenatória até o julgamento definitivo do recurso evitaria, consequentemente, o cumprimento direto da penalidade aplicada.

O Pacote Anticrime, por conseguinte, com a utilização da expressão "excepcionalmente", sugere que a execução provisória das condenações, em que a pena é igual ou superior a 15 anos, como já esclarecido, é a regra. Apenas em quadros atípicos, incomuns ou até "anormais", não haveria a efetivação imediata da sanção fixada.

Importante mencionar, nesse ponto, o tratamento diferenciado concedido pela Constituição aos crimes dolosos contra a vida. De maneira diversa do que ocorre nos crimes penais comuns, atribuiu-se ao próprio povo o poder de julgar a culpabilidade de seus semelhantes, e o fez garantindo a impossibilidade de alteração ou substituição da decisão pro- 
ferida. Conforme o art. 50, inciso XXXVIII, alínea “c”, da Carta Magna, "é reconhecida a instituição do júri, com a organização que lhe der a lei, assegurados: [...] c) a soberania dos veredictos" (BRASIL, 1988).

Essa garantia é, para tanto, conhecida como princípio da soberania dos vereditos. Visa assegurar, no momento da tomada de decisão, maior autonomia, independência e imparcialidade aos jurados, representantes da vontade popular, como também impedir que os órgãos do Poder Judiciário reapreciem os fatos e as provas que determinaram a responsabilidade penal reconhecida soberanamente pelo Júri, resguardadaa hipótese de o julgamento ser anulado quando evidenciada decisão manifestamente contrária à prova dos autos (art. 593, III, “d”, § $3^{\circ}$, do CPP).

Nesse viés, relevante suscitar o Habeas Corpus $\mathrm{n}^{\circ} 118.770 / \mathrm{SP}$, em que o Min. Luís Roberto Barroso redigiu a ementa e assentou o seu entendimento sobre a possibilidade da execução imediata das condenações proferidas pelo Tribunal Popular. No caso, embora a maioria dos ministros tenha votado no sentido de não conhecer da impetração ante a inadequação da via eleita, não havendo, portanto, expressa anuência dos demais membros do colegiado acerca da tese esboçada, a fundamentação do Ministro é utilizada para defender a medida, inclusive por Sérgio Moro, na época ocupando o cargo de Ministro da Justiça e Segurança Pública, quando apresentadas as alterações propostas pela Lei no $13.964 / 19$.

No mesmo sentido foi o seu voto no $\mathrm{HC}^{\circ}$ 140.449/RJ:

[...] nas condenações pelo Tribunal do Júri, sequer é necessário aguardar o julgamento de recurso em segundo grau de jurisdição, até porque o Júri é soberano e, consequentemente, o Tribunal de Justiça não tem como substituir a decisão do Júri. Eventualmente pode anulá-lo, como aliás foi o caso aqui relatado da tribuna, mas as estatísticas documentam que é irrisório o número de condenações pelo Júri anuladas pelos tribunais de justiça. $\mathrm{O}$ contrário até acontece com mais frequência, absolvições que venham a ser anuladas, mas condenações que venham a ser anuladas é um número irrisório. (BRASIL, 2018, p. 10). 
do Min. Dias Toffoli no julgamento conjunto das Ações Declaratórias de Constitucionalidade de $n^{\circ} \mathrm{s} 43,44$ e 54 :

Como se vê, a possibilidade de decretar prisão após a condenação em segunda instância, portanto, não é garantia de combate à impunidade ou de credibilidade do Poder Judiciário.

Por isso, entendo, desde sempre, que, nos crimes julgados pelo tribunal do júri, em razão da estatura constitucional desse órgão do Judiciário, mormente a soberania dos vereditos, a condenação deve ser imediatamente cumprida. (BRASIL, 2019b, p. 477).

Tal contexto denota que o princípio da soberania dos vereditos tem surgido como principal argumento para justificar as alterações trazidas pelo Pacote Anticrime, sustentando, para tanto, a possibilidade de cumprimento automático das puniçõescom base no "quantum" da pena fixada pelo Conselho de Sentença.

\section{OS PRINCÍPIOS DO ESTADO DE INOCÊNCIA E DO DUPLO GRAU DE JURISDIÇÃO}

Em contrapartida, uma segunda vertente alega que o princípio da soberania dos vereditos não é absoluto e, ao determinar a prisão do condenado sem o trânsito em julgado da sentença penal, os princípios da presunção de inocência e do duplo grau de jurisdição restariam violados.

Essa posição se tornou evidente no julgamento do $\mathrm{HC} \mathrm{n}^{\circ}$ 68.658/SP, em que se discutiu a compatibilidade do art. 593, III, “d”, do Código de Processo Penal, o qual dispõe sobre a desconstituiçāo da decisão do Conselho de Sentença "quando manifestamente contrária à prova dos autos" (BRASIL, 1941), com a soberania dos vereditos do Tribunal do Júri.O Min. Celso de Mello, relator, opinou no sentido de que a soberania ostenta valor meramente relativo, tendo em vista que as manifestações decisórias emanadas pelo Conselho de Sentençanão se revestem de intangibilidade jurídico processual (BRASIL, 1991, p. 8-9).

Desse modo, a soberania dos vereditos não deveria impossibilitar o acesso ao duplo grau de jurisdição, muito menos considerar o réu culpado antes do trânsito em julgado. Inevitável rememorar que os direitos 
e as garantias fundamentaisde todos os cidadãos estão dispostos no art. $5^{\circ}$, Título II, da Constituição Federal de 1988. Os primeiros são a base do Estado Democrático de Direito, limitando o ius puniendi e tendo como objeto imediato um bem específico do cidadão, ao passo que as garantias, também restringindo o exercício do poder estatal, são as medidas previstas para proteger e defender esses direitos, intrínsecos da sociedade.

O princípio da não culpabilidade é consagrado no art. $5^{\circ}$, inciso LVII, da Carta Magna, e refere-se à premissa de que ninguém será considerado culpado até o trânsito em julgado de sentença penal condenatória (BRASIL, 1988). É equivocadamente conhecido como princípio da "presunção" de inocência, uma vez que não se trata de uma suposição, mas sim uma afirmação do estado de inocência, até o trânsito em julgado da decisão, de todo aquele que estiver submetido à persecução penal (RANGEL, 2003, p. 25). Impõe-se ao Poder Judiciário a observância de regras relacionadas ao tratamento, estabelecendo que o réu não pode sofrer restrições pessoais tão somente sob a alegação de probabilidade de condenação, e ao fundo probatório, segundo as quais o ônus probatório incumbe àquele que acusa (PACELLI, 2020, p. 81). Quanto às normas de tratamento, o estado de inocência veda a antecipação das consequências penais, sendo aceita a imposição da prisão preventiva apenas em casos de extrema necessidade.

Infere-se o voto do Min. Marco Aurélio no já mencionado $\mathrm{HC} \mathrm{n}^{\circ}$ 140.449/RJ, reiterando um de seus posicionamentos sobre o tema:

Não se pode potencializar o decidido pelo Pleno no habeas corpus $\mathrm{n}^{\mathrm{o}}$ 126.292, por maioria, em 17 de fevereiro de 2016. Precipitar a execução da sanção importa antecipação de culpa, por serem indissociáveis. Conforme dispõe o inciso LVII do artigo $5^{\circ}$ da Constituição Federal, "ninguém será considerado culpado até o trânsito em julgado de sentença penal condenatória", ou seja, a culpa surge após alcançada a preclusão maior. Descabe inverter a ordem do processo-crime - apurar-se para, selada a culpa, prender-se, em verdadeira execução da pena. (BRASIL, 2018, p. 6). 
A esse respeito, nas palavras do Min. Gilmar Mendes:

Antes de se ter a definição da culpa, não se pode prender para impor pena. As hipóteses de prisão antes da formação da culpa seriam aquelas elencadas como prisões cautelares (preventiva e temporária). Portanto, fixada a primeira premissa: ninguém pode ser punido sem ser considerado culpado; ninguém pode ser preso sem ter a sua culpa definida por ter cometido um crime; não se pode executar uma pena a alguém que não seja considerado culpado.

E, a partir disso, a segunda premissa é decorrência clara do texto constitucional: "ninguém será considerado culpado até o trânsito em julgado de sentença penal condenatória". Se "não se pode executar uma pena a alguém que não seja considerado culpado" e "ninguém será considerado culpado até o trânsito em julgado de sentença penal condenatória", conclui-se que não se pode executar uma pena até o trânsito em julgado de sentença penal condenatória. (BRASIL, 2019e, p. 12).

Depreende-se, assim, que a tese do Min. Luís Roberto Barroso no RE $\mathrm{n}^{\mathrm{o}}$ 1.235.340, até o presente momento ainda em pauta, representaria, nesse viés, uma presunção de culpa em fase processual que ainda permite a modificação da sentença. A Carta Constitucional deixa claro, também de acordo com essa corrente, a excepcionalidade de toda forma de prisão antes ou durante o processo penal e, somente com a devida motivação e objetivando a proteção da ordem pública, poderiam ser impostas as prisões cautelares.

Por sua vez, o direito ao duplo grau de jurisdição é a garantia judicial mínima, instituída pelo art. $8^{\circ}$, item 2, alínea "h", do Pacto de São José da Costa Rica, de que toda pessoa acusada de um delito tem "direito de recorrer da sentença a juiz ou tribunal superior"(1969). As qualidades de direito fundamental, com caráter judicial e de garantia constitucional do processo, derivam da consagração da tese da supralegalidade pela Corte Suprema, prevista no art. $5^{\circ}, \S 2^{\circ}$, da Lei Maior, e conferida à Convenção Interamericana de Direitos Humanos, ratificada pelo Brasil em 1992. Esse princípio proporciona uma nova análise da matéria, de fato e de direito, por órgão hierarquicamente superior. Busca-se evitar a falibilidade humana e possíveis arbitrariedades, além de proteger a 
condição de inocência, a qual não pode ser afastada com uma única sentença condenatória prolatada por órgão jurisdicional singular.

Salvaguardando a possibilidade de compatibilidade entre o princípio da soberania dos vereditos e o do duplo grau de jurisdição, assevera Guilherme de Souza Nucci:

Não há princípios absolutos e supremos, devendo haver composição entre todos, mormente os que possuem status constitucional. Por isso, afirmar que a soberania dos veredictos populares precisa ser fielmente respeitada não significa afastar a possibilidade de se submeter a decisão prolatada no Tribunal do Júri ao duplo grau de jurisdição.

O ponto relevante é harmonizar os dois princípios. O recurso é viável, embora o mérito deva ser preservado. Nada impede que a parte, sentindo-se prejudicada, ingresse com o recurso cabível. Este, no entanto, se provido, deve remeter o caso a nova avaliação pelo Tribunal Popular. Com isso, garante-se a possibilidade de uma revisão, respeitando-se, ao mesmo tempo, a soberania da instituição do júri. (NUCCI, 2008, p. 367)

Vinicius Gomes de Vasconcellos (2019) sustenta que o direito de recurso sobre a condenação é um direito-garantia. $\mathrm{O}$ acusado tem $\mathrm{o}$ direito de submeter a decisão judicial ao reexame por tribunal diverso e superior ao primeiro, ao mesmo tempo em que essa revisão consiste em um instrumento de garantia de que outros também serão efetivados, respeitando as regras do devido processo penal em todo caso.

Corroborando com a posiçãode que a execução provisória da pena imposta pelo Júri configura manifesta ilegalidade, o Min. Jorge Mussise manifestou no sentido de que a medida é passível de correção por meio do remédio constitucional do habeas corpus:

[...] constata-se que a execução provisória da pena foi determinada pelo Juiz presidente do Tribunal popular antes mesmo da interposição do recurso de apelação cabível para a instância ad quem, o que configura manifesta ilegalidade, passível de correção de ofício por esta Corte Superior de Justiça. (BRASIL, 2017a, p. 17).

Isso porque, levando em consideração que o duplo grau de jurisdiçãos e trata de um direito fundamental do acusado, o cumprimento 
imediato da condenação poderia representar uma restrição concreta ao seu direito de obter a reavaliação de um pronunciamento contrário ao próprio interesse.

\section{ANÁLISE ACERCA DA INCONSTITUCIONALIDADE DA EXECUÇÃO IMEDIATA DAS PENAS IMPOSTAS PELO TRIBUNAL POPULAR}

Apresentados os posicionamentos sobre o tema, didaticamente divididos em duas correntes, verifica-se a existência de um conflito entre os princípios do estado de inocência - relacionado com o direito fundamental de liberdade do acusado - e o da soberania dos vereditos busca impedir a impunibilidade e assegurar a efetividade da lei penal. Utilizar-se-á a teoria de Robert Alexy, aprofundadas as considerações de Ronald Dworkin, para analisar os principais argumentos levantados por elas.

Alexy reconhecia que as normas jurídicas se dividiam em regras e princípios, diferenciados com base nas suas estruturas e formas de aplicação (SILVA, 2002, p. 3). As regras representam "mandados definitivos" e são aplicadas pela lógica da subsunção, isto é, a partir do momento que é identificada uma situação de fato prevista abstratamente na regra, torna-se necessário incidir a consequência jurídica determinada por ela. Os direitos fundamentais seriam consagrados na Constituição sob a forma de princípios, os quais funcionariam como "mandados de otimização" e seriam definidos como "normas que ordenam que algo seja realizado na maior medida possível dentro das possibilidades jurídicas e fáticas existentes" (ALEXY, 2008, p. 90). Em um conflito entre regras, trabalha-se, assim, com o plano da validade, enquanto, tratando-se de princípios, necessário exercer um sopesamento moral a partir do princípio da proporcionalidade.

A partir dessa distinção, depreende-se que, segundo sua teoria, o chamado princípio da proporcionalidade é, na verdade, uma regra, uma vez que é aplicado de forma constante, por meio da subsunção (SILVA, 2002, p. 4). Inevitável reconhecer sua importância nos casos em que 
uma decisão judicial, destinada a assegurar um direito ou garantia fundamental, acaba restringindo outro. O objetivo da aplicação da máxima da proporcionalidade é, justamente, impedir que a restrição desses direitos tome dimensões desproporcionais (SILVA, 2002, p. 2), exigindo-se que se estabeleça o peso relativo de cada um deles.

Retorna-se ao voto do Min. Luís Roberto Barroso no Recurso Extraordinário $\mathrm{n}^{\mathrm{o}} 1.235 .340$, ainda em andamento, para melhor compreensão. Sua manifestação foi no sentido de que, em condenações por crimes dolosos contra a vida, a responsabilidade penal do acusado já estaria assentada, soberanamente, pelo Júri, quadro esse que impossibilitaria a reapreciação de fatos e provas. Alegou que o princípio do estado de inocência mereceria menor peso ao ser ponderado com o interesse constitucional à efetividade da lei penal (BRASIL, 2020, p. 21).

A ponderação entre princípios deve se dar a partir das três sub-regras da proporcionalidade, observando essa ordem: adequação, necessidade e proporcionalidade em sentido escrito, esta também conhecida como razoabilidade. Uma medida é considerada adequada quando contribui, ainda que minimamente, para alcançar o fim ou o objetivo pretendido; necessária, quando não existir outro meio, igualmente eficaz, que limite em menor intensidade o direito fundamental atingido; e, por fim, proporcional em sentido estrito, quando os motivos que fundamentam a sua adoção tenham peso suficiente para justificar a restrição (ALEXY, 2008, p. 117-121).

Em harmonia com a ponderação alexyana, se, para impedir a impunibilidade, o Supremo Tribunal Federal decidisse no sentido de permitir a execução provisória da pena imposta pelo Tribunal do Júri: a medida seria adequada e necessária de acordo com a regra da proporcionalidade, uma vez que promoveria a satisfação do objetivo pretendido e, malgrado existam outros meios que restrinjam em menor intensidade a liberdade do acusado, nenhuma delas teria a mesma eficácia da citada. Somente após o sopesamento moral exigido pela proporcionalidade em sentido estrito, constata-se que não há como não decidir em favor da liberdade do acusado - presumindo sua inocência -, embora essa escolha possa acarretar, teoricamente, menor grau de proteção à ordem pública. 
Cabe ressaltar que, com o intuito de garantir a aplicação da lei penal, sem, contudo, violar o estado de inocência, a lei prevê a possibilidade da prisão cautelar, mais especificamente a prisão preventiva. Estabelece o art. 312 do Código Processual Penal:

A prisão preventiva poderá ser decretada como garantia da ordem pública, da ordem econômica, por conveniência da instrução criminal ou para assegurar a aplicação da lei penal, quando houver prova da existência do crime e indício suficiente de autoria e de perigo gerado pelo estado de liberdade do imputado. (BRASIL, 1941).

Deve ser aplicada, todavia, em casos de extrema necessidade, quando insuficientes as demais medidas cautelares, analisando-senão a culpabilidade do acusado, porquanto representaria antecipação de cumprimento de pena, mas os indícios de autoria e materialidade do delito que, baseados em elementos concretos, retratem o risco concreto e efetivo ao regular andamento do processo. De acordo com o art. $313, \S 2^{\circ}$, do mesmo diploma processual:

Nos termos do art. 312 deste Código, será admitida a decretação da prisão preventiva:

[...]

$\S 2^{\circ}$ Não será admitida a decretação da prisão preventiva com a finalidade de antecipação de cumprimento de pena ou como decorrência imediata de investigação criminal ou da apresentação ou recebimento de denúncia. (BRASIL, 1941).

Tais considerações apontam que a ponderação entre direitos fundamentais, tanto quanto a imposição da prisão cautelar preventiva, deve respeitar o princípio da dignidade humana. Ana Paula de Barcellos ensina que a solução de um conflito entre princípios deve ser sempre favorável àqueleque mais "prestigia a dignidade humana" (2006, p. 108113). Deve prevalecer, portanto, o princípio que fortalece essa ideia, na hipótese vertente a liberdade do acusado, não o que prestigia o direito de punir. A primazia da soberania dos vereditos significaria subverter uma garantia, um instrumento de proteção contra a dignidade, justamente daquele que a detém. Com a execução automática da sanção imposta, o acusado poderia ser submetido, antecipadamente, a uma pena 
incompatível com a que seria estabelecida ao fim da ação penal, atendendo-se exclusivamente ao interesse do Estado.

A propósito, nas palavras de Fernando da Costa Tourinho Filho:

[...] entre manter a soberania dos veredictos intangível e procurar corrigir um erro em benefício da liberdade, obviamente o direito de liberdade se sobrepõe a todo e qualquer outro, mesmo porque as liberdades públicas, notadamente as que protegem o homem do arbítrio do Estado, constituem uma das razões do processo de organização democrática e constitucional do Estado. (TOURINHO FILHO, 1997, p. 369).

De se anotar, no que diz respeito ao duplo grau de jurisdição, a possibilidade de decisões arbitrárias no âmbito do Júri. O Tribunal Popular, instituído no Brasil, em 1822, por Dom Pedro I, é composto pelo Juiz-Presidente e pelo Conselho de Sentença, integrado por sete jurados leigos selecionados por meio de sorteio devidamente regulado por lei. A direção e a condução do procedimento cabem ao Juiz-Presidente, que, após as conclusões apresentadas pelo corpo de jurados, expõe o conteúdo da decisão e forma o convencimento judicial final. Essas conclusões são levantadas a partir das respostas aos quesitos, previamente formulados, sobre as questões de fato e de direito do caso em apreço (PACELLI, 2020, p. 884).

O fato de ser um órgão coletivo, não torna o Conselho de Sentença inteiramente imparcial ou garantidor, considerando que suas decisões são secretas, não fundamentadas e tomadas pela íntima convicção, por livre convencimento imotivado. Por ser composto de pessoas do povo, erros na apreciação dos fatos e provas podem ser constatados e, com o intuito de reduzir equívocos nos julgamentos, que se garante o duplo grau de jurisdição. Assim, a garantia da soberania dos vereditos deve ser entendida em termos, uma vez que as decisões do Tribunal do Júri possuem caráter meramente relativo e não se revestem de intangibilidade jurídico-processual (BRASIL, 1991, p. 8-9), cedendo, nesse caso, ao direito de reexame da condenação. Não devem, assim, ser consideradas incontestáveis e ilimitadas, porquanto podem, inclusive, sofrer impug- 
nação, quando manifestamente contrária à prova dos autos, nos termos do art. 593, III, “d”, do Códex Processual Penal.

Por fim, ainda que, no RE $\mathrm{n}^{\circ} 1.235 .340$, o Min. Barroso sustente seu entendimento independente do importe da pena aplicada, convém mencionar a alteração, totalmente insustentável, apresentada pelo Pacto Anticrime, a qual estabelece, como regra, a execução provisória nas condenações com penas iguais ou superiores a 15 anos. Não há fundamento, ou qualquer tipo de explicação, que respalde essa distinção criada pelo legislador, o qual determina uma incidência maior da soberania dos vereditos em casos envolvendo determinado "quantum" de pena. O montante da condenação imposto pelo Júri, por conseguinte, não deveria ser utilizado para amparar a antecipação do seu cumprimento, uma vez que permanece sujeito a modificações.

Frisa-se que a prisão preventiva, se presentes os requisitos autorizadores, pode ser imposta nesses casos - após a condenação -, sempre com a devida fundamentação e a depender da conjuntura. No entanto, o instituto da prisão ex lege, isto é, automática e sem fundamentação concreta, imposta por força de lei, já foi declarada inconstitucional na Ação Direta de Inconstitucionalidade $n^{0} 3112$. Trata-se de uma espécie de cárcere sem a apreciação pelo magistrado acerca da adequação, necessidade, proporcionalidade e excepcionalidade da medida. No julgamento, foi declarada a incompatibilidade do art. 21 do Estatuto do Desarmamento (Lei $n^{0} 10.826 / 03$ ), o qual previa a impossibilidade de liberdade provisória para os crimes estabelecidos entre os arts. $16 \mathrm{e}$ 18 da mesma lei, com os princípios constitucionais da presunção de inocência, da ampla defesa e do contraditório e da obrigatoriedade de fundamentação dos decretos de prisão pela autoridade judiciária competente. Foi firmada a tese de que "o texto magno não autoriza a prisão ex lege, em face dos princípios da presunção de inocência e da obrigatoriedade de fundamentação dos mandados de prisão pela autoridade judiciária competente" (BRASIL, 2007, p. 2).

Com efeito, no julgamento do $\mathrm{HC}^{\circ}$ 104.339, o Supremo Tribunal Federal entendeu, nos termos do voto do relator Min. Gilmar Mendes, que a prisão processual ex lege do agente, acusado por tráfico de drogas, 
constituía "inequívoca antecipação de pena” (BRASIL, 2012, p. 9), indo de encontro com a exigência de fundamentação dos decretos prisionais e estabelecendo uma presunção de necessidade da prisão, "afastando a intermediação valorativa de seu aplicador” (BRASIL, 2012, p. 14).

No mais, recorda-se o entendimento pacificado da Corte quanto à impossibilidade de decretação de prisão preventiva com base na gravidade abstrata das imputações delitivas (BRASIL, 2015a; BRASIL, 2017c), além de que suposições acerca do perigo que decorre do estado de liberdade do imputado (periculumlibertatis), sem respaldo concreto, também não são suficientes para embasar a prisão processual (BRASIL, 2015b; BRASIL, 2017d). Logo, se a prisão preventiva não pode ser imposta com fundamento em presunções ou na gravidade abstrata do crime supostamente praticado, que dirá executar a pena automaticamente em condenações que ainda podem ser alteradas.

À vista de todo o exposto, é preciso considerar, portanto, que o estabelecido pela Lei n ${ }^{\circ} 13.964 / 19$, ao impor a execução provisória automaticamente e, como regra, em condenações que ainda não percorreram toda a cadeira recursal, contraria os entendimentos já assentados pelo Supremo Tribunal Federal e não se mostra como a melhor alternativa diante da necessidade de se assegurar a proteção dos princípios e das garantias fundamentais, basilares do Estado Democrático de Direito.

\section{CONCLUSÃO}

Aos limites e objetivos do que se propôs, o artigo buscou analisar a compatibilidade da execução provisória da pena após decisão condenatória de primeiro grau no Tribunal Popular do Júri com a Constituição Federal e com a própria normatividade do Código de Processo Penal. Para melhor compreensão, foi necessário expor a construçãodos entendimentos firmados no Supremo Tribunal Federal até a discussão atual, com repercussão geral no Recurso Extraordinário no ${ }^{\circ} 1.235 .340$ ainda em pauta.

Por conseguinte, discutiu-se as posições favoráveis e contrárias em relação ao tema. O que se constatou foi o fato de que a primeira corrente 
trata-se, na verdade, de uma posição mais isolada do Min. Luís Roberto Barroso, utilizando, como fundamento, principalmente, o princípio da soberania dos vereditos, levando em consideração que a responsabilidade penal do réu já é definida soberanamente nas condenações pelo Tribunal Popular, tendo em mente que, mesmo com a interposição de apelação, não poderiam ser reapreciados os fatos e as provas do caso. Aduz, ainda, que a efetividade da lei penal deve prevalecer em detrimento da liberdade do acusado. Ademais, apresentou-se a Lei no 13.964, de 2019, que, recorrendo às mesmas justificativas, passou a estabelecer a execução provisória como regra em decisões do Júri com penas iguais ou superiores a 15 (quinze) anos de reclusão.

Dentre os argumentos contrários, defendidos especialmente pela $2^{\text {a }}$ Turma do Supremo Tribunal Federal e pela $5^{\text {a }}$ Turma do Superior Tribunal de Justiça, a pesquisa se debruçou sobre o princípio do duplo grau de jurisdição, recepcionado ao ordenamento jurídico brasileiro pela Convenção Interamericana de Direitos Humanos, demonstrando-se sua natureza de garantia do devido processo legal ao acesso à instância recursal superior; e o princípio do estado de inocência, previsto no art. $5^{\circ}$, inciso LVII, da Carta Magna, enfático ao exigir o trânsito em julgado da sentença penal condenatória para o início do cumprimento da pena.

Considerando a importância do debate em questão, o conflito entre os princípios da soberania dos vereditos e da condição de inocência foi analisado a partir da regra da proporcionalidade e suas sub-regras, conforme a teoria dos direitos fundamentais de Robert Alexy. Aferiu-se que a medida da execução provisória nas condenações do Júri seria adequada e necessária, mas não satisfaz o critério da proporcionalidade em sentido estrito, uma vez que viola o núcleo essencial do direito à liberdade - restringindo-o e, consequentemente, inviabilizando o estado de inocênciados acusados até o trânsito em julgado da decisão. A busca pela efetividade das decisões condenatórias, portanto, ainda que em um primeiro momento se mostre louvável, não prevalece em detrimento dos direitos e das garantias assegurados ao réu. 
Posteriormente, verificou-se que a soberania dos vereditos não é absoluta e pretender a execução imediata de um julgado de primeiro grau, sem considerar o direito de recurso do acusado, é incompatível com a Constituição da República, visto que a apelação de decisão do júri pode resultar em reanálise de fatos e provas ao convocar novo julgamento. Ademais, ficou demonstrado que a prisão ex lege, sem fundamentação e imposta automaticamente por força de lei - praticamente o que se verifica na nova alteração imposta pelo Pacote Anticrime -, foi declarada inconstitucional por ofender o dever de motivação das decisões judiciais. Apenas após a condenação, em casos de extrema necessidade, a prisão preventiva pode ser aplicada com o desígnio de garantir a aplicação da lei penal e, concomitantemente, respeitar o estado de inocência; todavia, não pode ser decretada em razão do clamor público ou em face da gravidade do crime, muito menos por suposições sem respaldo nos autos, porquanto essas motivações não se adequam à essencial instrumentalidade cautelar dessa medida restritiva de liberdade.

A partir do estudo, foi constatado que a execução provisória da pena no primeiro grau do Tribunal do Júri, em conformidade com a hipótese inicial apresentada, é incompatível com a efetiva proteção dos direitos e das garantias fundamentais assegurados ao acusado durante toda a persecução penal, violando, preponderantemente, o princípio da condição de inocência.

\section{REFERÊNCIAS}

ALEXY, Robert. Teoria dos direitos fundamentais. Tradução de Virgílio Afonso da Silva. São Paulo: Malheiros, 2008. (título original: "Theorie der Grundrechte"). Disponível em:http://noosfero.ucsal.br/ articles/0010/3657/alexy-robert-teoria-dos-direitos-fundamentais.pdf. Acesso em:7fev. 2021.

BARCELLOS, Ana Paula de. Alguns parâmetros normativos para a ponderação constitucional. In: A nova interpretação constitucional: ponderação, direitos fundamentais e relações privadas. 3.ed. Rio de Janeiro: Renovar, 2006. 
BRASIL. [Constituição (1988)]. Constituição da República Federativa do Brasil. Brasília, DF: Presidência da República, 1988. Disponível em: http://www.planalto.gov.br/ccivil_03/constituicao/constituicao. htm. Acesso em: 4 fev. 2021.

BRASIL. Decreto $n^{\circ}$ 678, de 6 de novembro de 1992. Promulga a Convenção Americana sobre Direitos Humanos (Pacto de São José da Costa Rica), de 22 de novembro de 1969. Brasília, DF: Presidência da República, 1992. Disponível em: http://www.planalto.gov.br/ccivil_03/ decreto/d0678.htm. Acesso em: 4 fev. 2021.

BRASIL. Decreto-lei no 3.689, de 3 de outubro de 1941. Código de Processo Penal. Brasília, DF: Presidência da República, 1941. Disponível em: http://www.planalto.gov.br/ccivil_03/decreto-lei/del3689compilado.htm. Acesso em: 4 fev. 2021.

BRASIL. Lei $\mathbf{n}^{\mathbf{1}} \mathbf{1 3 . 9 6 4}$, de 24 de dezembro de 2019. Aperfeiçoa a legislação penal e processual penal. Brasília, DF: Presidência da República, 2019a. Disponível em: http://www.planalto.gov.br/ccivil_03/_ Ato2019-2022/2019/Lei/L13964.htm. Acesso em: 4 fev. 2021.

BRASIL. Superior Tribunal de Justiça. Recurso em Habeas Corpusn ${ }^{\mathbf{0}}$ 84406/RJ. Relator: Jorge Mussi. Diário de Justiça Eletrônico, Brasília, 12dez. 2017a. Disponível em:https://scon.stj.jus.br/SCON/ GetInteiroTeorDoAcordao?num_registro $=201701110868 \& d t \_p u b l i c a-$ cao $=01 / 02 / 2018$. Acesso em: 12 fev. 2021.

BRASIL. Supremo Tribunal Federal. Ação Declaratória de Constitucionalidade no 43/DF. Relator: Marco Aurélio. Diário de Justiça Eletrônico, Brasília, 7 de novembro de 2019b. Disponível em: http:// portal.stf.jus.br/processos/downloadPeca.asp?id=15344948872\&ext=. pdf. Acesso em: 4 fev. 2021.

BRASIL. Supremo Tribunal Federal. Ação Declaratória de Constitucionalidade n⿳4十/DF. Relator: Marco Aurélio. Diário de Justiça Eletrônico, Brasília, 7 de novembro de 2019c. Disponível em: http://portal. stf.jus.br/processos/downloadPeca.asp? $\mathrm{id}=15344949163 \&$ ext $=$.pdf. Acesso em: 4 fev. 2021. 
BRASIL. Supremo Tribunal Federal. Ação Declaratória de Constitucionalidade n⿳5十/DF. Relator: Marco Aurélio. Diário de Justiça Eletrônico, Brasília, 7 de novembro de 2019d. Disponível em:http://portal.stf. jus.br/processos/downloadPeca.asp? $\mathrm{id}=15344949506 \&$ ext $=$.pdf. Acesso em: 4 fev. 2021.

BRASIL. Supremo Tribunal Federal. Ação Direta de Inconstitucionalidade $n^{0}$ 3112/DF. Relator: Ricardo Lewandowski. Diário de Justiça Eletrônico, Brasília, 2 de maio de 2007. Disponível em: http://redir.stf. jus.br/paginadorpub/paginador.jsp?doc TP=AC\&docID=491806. Acesso em: 10 fev. 2021.

BRASIL. Supremo Tribunal Federal. Embargos de Declaração no Habeas Corpus n⿳163814/MG. Relator: Gilmar Mendes. Diário de Justiça Eletrônico, Brasília, 19 de novembro de 2019e. Disponível em: https:// portal.stf.jus.br/processos/downloadPeca.asp? $\mathrm{id}=15344022545 \& \mathrm{ext}=$. pdf. Acesso em: 7 fev. 2021.

BRASIL. Supremo Tribunal Federal. Habeas Corpus n⿳608658/SP. Relator: Celso de Mello. Diário de Justiça Eletrônico, Brasília, 6 de agosto de1991. Disponível em:http://redir.stf.jus.br/paginadorpub/paginador. jsp?docTP=AC\&docID=71129. Acesso em: 12 fev. 2021.

BRASIL. Supremo Tribunal Federal. Habeas Corpus n 84078/MG. Relator: Eros Grau. Diário de Justiça Eletrônico, Brasília, 25 de fevereiro de 2010. Disponível em:http://redir.stf.jus.br/paginadorpub/paginador.jsp?doc TP=AC\&docID=608531. Acesso em: 8 fev. 2021.

BRASIL. Supremo Tribunal Federal. Habeas Corpus n⿳0104339/MG. Relator: Gilmar Mendes. Diário de Justiça Eletrônico, Brasília,10 de maio de 2012. Disponível em:http://redir.stf.jus.br/paginadorpub/paginador.jsp?docTP=TP\&docID=3164259. Acesso em: 8 fev. 2021.

BRASIL. Supremo Tribunal Federal. Habeas Corpus n⿳118770/SP. Relator: Marco Aurélio. Diário de Justiça Eletrônico, Brasília, 17 de março de 2017b. Disponível em:https://redir.stf.jus.br/paginadorpub/ paginador.jsp?docTP=TP\&docID=12769406. Acesso em: 10 fev. 2021. 


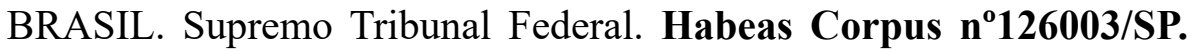
Relator: Teori Zavascki. Diário de Justiça Eletrônico, Brasília, 30 de junho de 2015a. Disponível em: http://redir.stf.jus.br/paginadorpub/paginador.jsp?docTP=TP\&docID=9594733. Acesso em: 12 fev. 2021.

BRASIL. Supremo Tribunal Federal. Habeas Corpus n⿳126292/SP. Relator: Teori Zavascki. Diário de Justiça Eletrônico, Brasília,17 de maio de 2016. Disponível em:http://redir.stf.jus.br/paginadorpub/paginador.jsp?docTP=TP\&docID=10964246. Acesso em: 8 fev. 2021 .

BRASIL. Supremo Tribunal Federal. Habeas Corpus no 130803/SP. Relator: Teori Zavascki. Diário de Justiça Eletrônico, Brasília, 1 de dezembro de 2015b. Disponível em: http://redir.stf.jus.br/paginadorpub/ paginador.jsp?docTP=TP\&docID=10126533. Acesso em: 12 fev. 2021 .

BRASIL. Supremo Tribunal Federal. Habeas Corpus no 139325/MG. Relator: Gilmar Mendes. Diário de Justiça Eletrônico, Brasília, 27 de junho de 2017c. Disponível em:http://redir.stf.jus.br/paginadorpub/paginador.jsp?docTP=TP\&docID=13328165. Acesso em: 12 fev. 2021.

BRASIL. Supremo Tribunal Federal. Habeas Corpus nº140449/RJ. Relator: Marco Aurélio. Diário de Justiça Eletrônico, Brasília, 06 de novembro de 2018. Disponível em:http://redir.stf.jus.br/paginadorpub/ paginador.jsp?docTP=TP\&docID=748979180. Acesso em: 6 fev. 2021 .

BRASIL. Supremo Tribunal Federal. Habeas Corpus no 143065/RJ. Relator: Ricardo Lewandowski. Diário de Justiça Eletrônico, Brasília, 6 de junho de 2017d. Disponível em: http://redir.stf.jus.br/paginadorpub/ paginador.jsp?docTP=TP\&docID=14274892. Acesso em: 12 fev. 2021.

BRASIL. Supremo Tribunal Federal. Recurso Extraordinário n⿳1口235340/SC. Voto relator: Luís Roberto Barroso, 24 de abril de 2020. Disponível em: https://migalhas.uol.com.br/arquivos/2020/4/6DAC9D4C675685_barroso.pdf. Acesso em: 5 fev. 2021.

NUCCI, Guilherme de Souza. Tribunal do júri. São Paulo: Editora Revista dos Tribunais, 2008. 
PACELLI, Eugênio. Curso de processo penal. 24. ed. São Paulo: Atlas, 2020.

RANGEL, Paulo. Direito processual penal. Rio de Janeiro: Lumen Juris, 2003.

SILVA, Luís Virgílio Afonso da. O proporcional e o razoável. Revista dos Tribunais, São Paulo, v.91, n.798, p. 23-50, 2002. Disponível em: https:/constituicao.direito.usp.br/wp-content/uploads/2002-RT798-Proporcionalidade.pdf. Acesso em: 13 fev. 2021.

TOURINHO FILHO, Fernando da Costa. Código de processo penal comentado. São Paulo: Saraiva, 1997.

VASCONCELLOS, Vinicius Gomes de. Direito ao recurso no processo penal: conteúdo e dinâmica procedimental para um controle efetivo da sentença condenatória. São Paulo: Thomson Reuters Brasil, 2019.

Recebido em: 19/03/2021 Aprovado em: 10/08/2021 